\title{
Włodzimierz Januszkiewicz
}

Institute of Foreign Trade and European Studies, Warsaw School of Economics

\author{
Book Review \\ Krzysztof Falkowski - „Międzynarodowa \\ konkurencyjność gospodarek Białorusi, Rosji \\ i Ukrainy” („International Competitiveness of \\ the Economies of Belarus, Russia and Ukraine"), \\ Warsaw School of Economics, \\ Warsaw 2013, p. 248
}

Polish economists have long been interested in our Eastern neighbours' economies, which are among our largest foreign trade and, more widely, economic partners. Falkowski has been observing, researching, and analyzing economic processes in Belarus, Russia and Ukraine for many years and has published a number of papers and publications on this interesting subject. This work about the ability of these countries to compete and innovate, is a welcome addition to the author's own body of work on that region, as well as the more general, worldwide discussion about innovation and competition now taking place among economists.

The book consists of an introduction, four chapters, a conclusion, a bibliography and a rich statistical annex, including 18 tables. In the introduction, the author explains the genesis of the book, and defines an economy's international competitiveness. The remainder of the book is a careful elaboration of his analysis of the three countries economies using country-specific features in the context of cogently explained data limitations.

Chapter I presents the theoretical aspects of international competitiveness of economies, i.e., the relevant definitions, the nature of international competitiveness of an economy and the factors determining it. In so doing, he discusses the different views of several of the most renowned specialists in the field of competitiveness both in Poland 
(J. Misala, M. Gorynia, M.A. Weresa, W. Bieńkowski, J.W. Bossak, T. Dołęgowski), and abroad (P. Kurgman. M.E. Porter, J.H. Dunning, J.W. McArtur, J.D. Sachs). He also discusses the most important dilemmas for which a uniform position in economic science has not yet been reached.

In Chapter II, the author analyzes in detail the competitiveness of Russia and Ukraine in 2006-2012 based on the most reputable world rankings, but does not do so for Belarus, which is outside that data set. The World Economic Forum data ranks both Russia and Ukraine in very low and steadily deteriorating positions (Russia - 133 and Ukraine - 132 among 144 analyzed countries). The author rightly suggests that without “...quick and comprehensive systemic changes in how the public sphere as well as the business operate in these countries" this situation and negative trend is unlikely to be reversed, anytime soon. However, given their current political situation, it seems improbable - if not impossible - that these changes will be implemented quickly.

Chapter III analyzes the competitiveness of the countries in question with regard to foreign trade using a variety of schemes. The last chapter of the book deals with selected international competitive determinants of Belarus, Russia and Ukraine. Here, the author demonstrates his wide knowledge of the current economic situations in these countries, which are used to great effect in formulating insights of real value.

There are points in the book where a reader wants more data inputs and, perhaps, somewhat greater clarity in terminology and the uniform use of particular terms. For example, the data limitations cited by the author concerning Belarus could have been at least partially remedied by including the UNO report entitled „International World Economic Situation and Prospects”, issued yearly in New York. A discussion of the consequences of Belarus's growing negative trade balance, and an analysis of services turnover in Russia (which has undoubtedly affected Russia' balance of payments since in 2013, Russia ranked 8th on the list of largest importers of services, accounting for $2.8 \%$ of the world import) would have been welcome. And, on occasion, subtle language- related issues arise concerning such terms as "sectors", which does not translate well, as applied, from English to Polish.

None of which materially detracts from the author's primary purpose- that is, to not only answer the question "how it is", but to also explain why it has happened. And that, after all, is the crux of all good economic research.

In conducting that research, the author provides readers with solid evidence. There are 113 notes and over 65 bibliographic entries, four of which are the author's own publications.

This book fills a gap in the contemporary economic literature. It is the first comprehensive attempt at describing the international competitiveness of Belarus, Russia and Ukraine and the breadth of problems and deliberations presented on that issue - especially given the context of the current political events in Ukraine - make it a useful read not only for university students but also for business practitioners and politicians who are actively shaping Poland's economic relations with these three countries. 
A final suggestion or, rather, request. In this work, the author's opinion about the future of these states was rendered before the outbreak of full-scale war by Russia with Ukraine. Given the depth of Falkowski's region understanding, a future work describing Russia's invasion of Ukraine influence on both economies would be met with great interest of readers. 